\title{
Utilization of plastic waste into fuel (fuel oil) in Namo Bintang Village, Deli Serdang Regency
}

\author{
Mayang Sari Yeanny ${ }^{1 *}$, Riyanto Sinaga ${ }^{1}$, Isnaini Nurwahyuni ${ }^{1}$ \\ ${ }^{1}$ Department of Biology, Faculty of Mathematics and Natural Sciences, Universitas \\ Sumatera Utara \\ *Email: mayang_sy@yahoo.com
}

\begin{abstract}
Community service activities with the title: Utilization of Plastic Waste into Fuel Oil in Namo Bintang Village Deli Serdang Regency was planned in May to November 2019.This activity aim was to convert plastic waste into fuel which has economic value and is environmentally friendly. Community services implementation was by counselling, lectures, explanations of theories and techniques for processing plastic waste which was followed by the Namo Bintang Village Scavenger group, they listened and training to the material delivered by the community service team. Equipment for waste utilization is also very simple hence community groups can make it by themselves. Finally, monitoring and evaluation of the success of work in the field will be carried out by going directly to the field together, monitoring by visiting to find out whether the community can do it themselves.In addition, contact will be made by telephone to overcome the problems that arise.In general, community service activities have been successfully carried out and seen a good cooperative relationship between the Higher Education, especially the Implementation Team, and the community in Namo Bintang Village. Villagers realize the importance of saving the environment and at the same time improving their lives because they can make their fuel.
\end{abstract}

Keyword: plastic waste, fuel (fuel oil)

\section{INTRODUCTION}

Namo Bintang Village is a village close to the former Medan city landfill, based on this condition, most of the villagers have a livelihood as scavengers or used goods collectors to be resold to fulfil their living needs. Although the Landfill has been moved, there are still many who pursue the profession. This condition can be seen in the following table:

Table 1. Resident Composition based on the Livelihood

\begin{tabular}{llc}
\hline No & \multicolumn{1}{c}{ Livelihood } & Resident \\
\hline 1. & GE/Soldier/Police & 65 \\
2. & Private employees & 143 \\
3. & Second-hand collectors / scavengers & $\mathbf{2 4 1}$ \\
4. & Farmer & 256 \\
5. & Merchant & 67 \\
6. & Services Provider & 84 \\
7. & Retirement & 62 \\
8. & Labour & 87 \\
\hline & Total & 1005 \\
\hline
\end{tabular}

Source: Data from Namo Bintang Village

The people of Namo Bintang Village throw a lot of garbage, especially plastic waste in the river or burn it. Garbage often piles up on the side of roads and rivers, hence it disturbs the environment. Besides, garbage is scattered into the paddy fields because it is carried by the river. 
The rubbish piled up hence the drainage or river water flow is blocked. When rainfall is high and last long, it will cause flooding.

Namo Bintang villagers often burn plastic waste to reduce the amount of plastic waste in the environment even though the burned plastic will produce hydrogen sulfide gas (H2S) which can be toxic to the environment. Moreover, if there is a chloride compound $(\mathrm{Cl})$ in the plastic waste content that can produce dioxin (which causes cancer) when burned at low temperatures. A large amount of plastic waste produced causes the need for the treatment of plastic waste. A large amount of plastic waste produced causes the need for the treatment of plastic waste.

Another treatment is to recycle plastic waste where plastic waste is processed and converted into new plastic materials. However, this recycling process will only change plastic waste into a new form, not overcome the amount of plastic waste because when the plastic recycling product has lost its function, it will return to plastic waste.Therefore another method is needed to cope with a large amount of plastic waste, one of which is by processing plastic waste into alternative fuels by pyrolysis method. The advantage of the pyrolysis process is carried out in an atmospheric reduction (vacuum) reactor at temperatures up to $800 \mathrm{oC}$ [1]. Research on the use of various plastic waste into liquid fuels by pyrolysis is still being developed at this time [2] and can be used as a substitute fuel for fossil fuels [3].

Based on this condition, the Namo Bintang village Scavenger Group partners work together with the community service team to utilize plastic waste into fuel with the pyrolysis process. The pyrolysis process of plastic waste is the process of organic compounds decomposition in plastic through a heating process with little or no oxygen involved.With the use of plastic waste, the people of Namo Bintang Village receive knowledge and training in the use of plastic waste into fuel to increase the family's economy, while reducing environmental pollution.

\section{METHODS}

The method used in this activity will be carried out with a combination of counselling, training, hands-on practice and work evaluation. This activity was supported by the village chief and officials who will be assisting in the implementation of this activity by giving permission and contacting the Scavengers group, while the benefits obtained will increase the knowledge of human resources in terms of the use of plastic waste into fuel.

Scavenger groups act as objects of the utilization of plastic waste. The benefits gained will increase knowledge, in addition to saving the environment from waste, the scavengers group processes plastic waste into reusable or sold materials which will ultimately assist the economy and improve their lives.

\subsection{Plastic Waste Processing}

The process starts with the selection of plastic waste, especially those that are clear or colorless. Then cleaned and dried in the sun to dry. Plastic waste processing is very easy, practical, economical, and inexpensive, only takes a few hours and anyone can do it. The obstacle is that the plastic waste processing machine is rather expensive hence needs to be disseminated to Namo Bintang villagers.

The pyrolysis process was carried out for 60 minutes with variations in the temperature of $250 \mathrm{oC}, 300 \mathrm{oC}, 350 \mathrm{oC}$ and $400 \mathrm{oC}$. To maximize the results of pyrolysis, the pyrolysis process is carried out under vacuum. In addition, the reactor is filled with silica sand as a heat barrier and zeolite as a catalyst for the hydrocarbon cracking process. Most pyrolysis oil from PolyPropylene plastic waste was obtained at an operating temperature of $400 \mathrm{oC}$ as much as $27.05 \%$ while the most pyrolysis oil from Low Density PolyEthylene plastic waste was obtained at an operating temperature of $300 \mathrm{oC}$ as much as $37.43 \%$.The viscosity of pyrolysis oil approaches the viscosity value of gasoline. Density of pyrolysis oil is close to the density value of diesel and kerosene. The heating value of pyrolysis oil is close to the heating value of diesel and kerosene. At low temperatures the pyrolysis oil produced will tend to form a candle where the higher the pyrolysis operating temperature, the less wax will be produced [4] 
With appropriate technology products, surely, plastic waste can be managed well. One of them which is currently being developed is converting plastic waste into diesel fuel equivalent to premium and diesel fuel. The mechanism of this process uses pyrolysis, which heats the plastic at temperatures above $400 \mathrm{oC}$ without oxygen. Pyrolysis of $\mathrm{PP}$ plastic waste at $400 \mathrm{oC}$ will produce a lot of C9 hydrocarbon compounds which can condense at room temperature [5]. At that temperature, the plastic will melt and then turn to gas. During the process, the long chain of hydrocarbons will be cut into short chains. Furthermore, the cooling process is carried out on the gas hence it will condensate and form a liquid.This liquid will later become fuel, both in the form of gasoline and diesel fuel. To achieve better results and performance, a catalyst is added. Some parameters are very influential on the product produced, including temperature, time, and type of catalyst.Catalysts of the zeolite and silica-alumina types are widely used in this process. The use of catalysts is expected to reduce the reaction temperature, accelerate the rate of decomposition, and modify the final product.

\section{RESULT AND DISCUSSION}

The results obtained in this activity by providing knowledge with a combination of counseling, training, hands-on practice and work evaluation.With integrated waste management, it is expected that the Namo Bintang Village community groups, especially the Scavengers Group, will produce useful external products such as fuel. Besides as a free time filler for the community of scavengers, it is also a solution to the high cost of fuel today. Hence the garbage is really used, the garbage is no longer burned and thrown into the river as before. In the end, the village community could save the environment and improve the standard of living of their families.

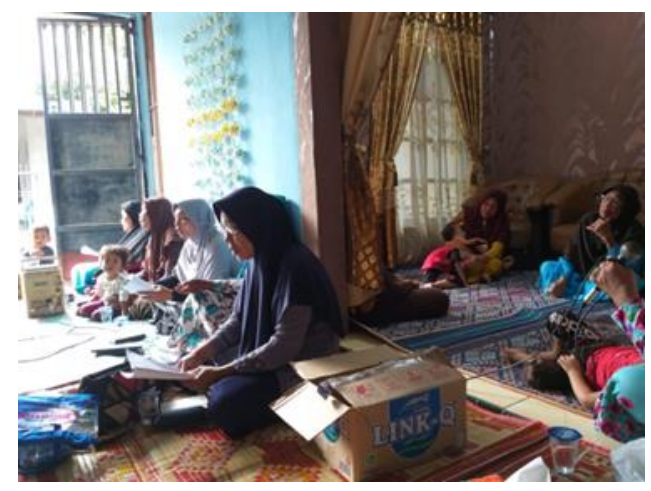

Figure 1. Counseling on the use of plastic waste

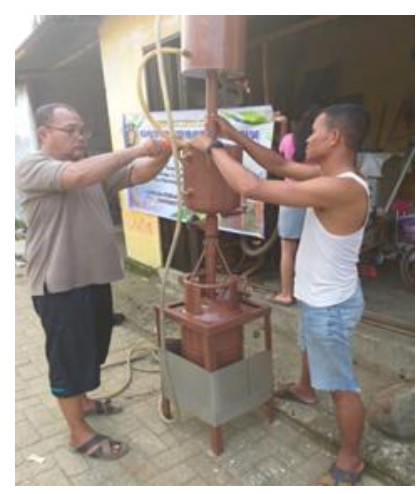

Figure 2. Training on the utilization of plastic waste

Targets and outcomes by processing plastic waste are expected by village community groups to gain knowledge (HR improvement) of turning plastic waste into fuel. Besides that, it 
becomes one of the most appropriate alternatives to fill the time and the environment becomes more awake because plastic waste that is difficult to decipher is not just thrown away but is processed into a more useful form.

In this community service, the Scavengers group processes plastic waste into fuel. Oil from pyrolysis of plastic waste produced contains $15-20 \%$ water [6]. The heating value of PP and LDPE plastic pyrolysis oil increases with the increase in pyrolysis operating temperature, which means that the higher the pyrolysis operating temperature, the higher the heating value of oil produced [7].Plastic waste processing is very easy, practical, economical, and inexpensive, only takes a few hours and anyone can do it.
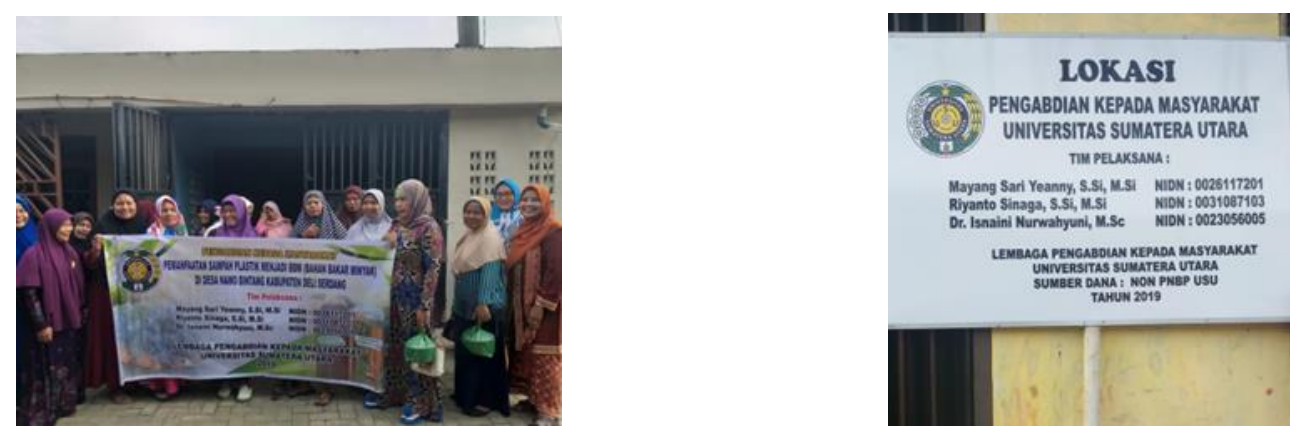

Figure 3. The team who conducted the social engangement from USU and communities at Namo Bintang

\section{CONCLUSION}

Based on the community service activities regarding the use of plastic waste into fuel in Namo Bintang village, Deli Serdang Regency, the following conclusions can be drawn listed below:

1. Utilization of plastic waste can be converted into fuel oil.

2. Utilization of plastic waste can provide economic and ecological value.

3. There is good collaboration between USU and the community in Namo Bintang village, Deli Serdang Regency.

\section{ACKNOWLEDGMENTS}

We would like to thank to the Rector of USU for finantial support by Mono Tahun Social Engagement Non PNBP 2019 and all participants who have helped the implementation of this Community Service.

\section{REFERENCES}

Ademiluyi, T.2007. Preliminary Evaluation of Fuel Oil Produced From Pyrolysis of Waste Sachets. Universityof Science and Technology. Nigeria.

Javier, Ignacio. Pyrolysis of PolyPropyleneBy Ziegler-Natta Ctalysts. Hamburg, 2006.

Moinuddin Sarker, Mohammad Mamunor Rashid, Muhammad Sadikur Rahman, dan Mohammed Molla.Conversion of Low Density Polyethylene (LDPE) and Polypropylene (PP) Waste PlastiksInto Liquid Fuel Using Thermal Cracking Process. British Journal of Environment and Climate Change. 2012. pp 1-11. 
Mayang Sari Yeanny, et.al. Utilization of plastic waste into fuel

Orabi, Rasha G. An InvestigasiThe KSA Enviromental Safety Using The Novel Microwave Pyrolysis For Recycling Waste Engines Oil. International Journal of Emerging Trends in Engineering and Development. 2015.

Ramadhan, A., dan Ali, M., 2013. Pengolahan Sampah Plastik Menjadi Minyak Menggunakan Proses Pirolisis, Jurnal Ilmiah Teknik Lingkungan Vol. 4 No. 1.

Suryo A.W., Adityo. (2011). Studi Sifat Minyak Pirolisis Campuran Sampah Biomassa dan Sampah Plastik Polypropylene (PP). Universitas Sebelas Maret. Surakarta.

Williams, Paul T. (Fluidised Bed Pyrolysis pf Low Density Polyethylene to Produce Petrochemical Feedstock.University of Leeds. 1998. 